\title{
ACQUISITION OF AGRICULTURAL LAND
}

\author{
Milena Trgovčević Prokić1, Milan Počuča ${ }^{2}$
}

\begin{abstract}
The expropriation is a forced deprivation of property in the public interest, and represents a form of restriction of property rights. The core issue of expropriation is a expropriated real estate. In determining fair monetary compensation, it is necessary to find criteria which protect both sides and find a balance and proportionality between social and individual interests. In the procedure of question of the just monetary compensation to the owner of the determining the compensation for the expropriated property the court has a duty to determine fair monetary compensation so that there is no unjust enrichment of the owners of the real estate and the impoverishment of the user of the expropriated property or vice versa. This paper analyzes the rules by which it is acted upon when there is a need to expropriate and determine a fair monetary compensation that should belong to the owner of the expropriated real estate.
\end{abstract}

Keywords: the expropriation of real estate, agricultural land, the agreement, fees, administrative authority contentious procedure, expert opinion, expertise.

JEL: $K 11, Q 15$

\section{Introduction}

Expropriation $^{3}$ is forcible deprivation of property rights in public interest and it represents a form of property rights limitation. In extreme cases, expropriation can be done in the benefits of a natural person. It happens in situations when establishes a legal official manner, for example, aiming to place waterworks, electrical or telephone cables.

The essential question of expropriation is the question of fair expropriation award. In determination of fair expropriation award, it is necessary to find criteria by which the rights of both parties will be protected, as well as the social and individual interest.

1 Milena Trgovčević Prokić Ph.D., First Basic Court in Belgrade, Kostolačka Street no. 89, Belgrade, Serbia, E-mail: milenaprok@gmail.com

2 Milan Počuča Associate Professor, Faculty of Law, University Business Academy, Geri Karolj Street no. 1, Novi Sad, Serbia, Phone: +381 21400 499, E-mail: pocuca@pravni-fakultet.info

3 Concept of expropriation is originated from a Latin word expropriare - ex (from) and proprius (property), which means - to deprive property.

EP 2016 (63) 4 (1281-1295) 
It means that the relation between ex-owner of immovability and expropriation user should be regulated in a way not to come to groundless enrichment of immovability owner and impoverishment of expropriation user and vice versa. ${ }^{4}$

The European Court of Human Rights' attitude is that only an owner has a right to peaceful pooling of assets and this right related obligation of a final user of expropriated property to pay the expropriation award for deprived property and right to enjoy it. European legal system guarantees that no one can be deprived of property rights before he is provided with the fair expropriation award.

According to some legal writers (lawyers), the expropriation award for expropriated immovability can be understood also as a compulsory purchase order, where consent of will, as an important element of a contract of sale replaces the law or as equal relationship sui generis or as a single act of public authority which operates constitutively (See more: Britvic Vetma, 2009).

In domestic and some legal systems, for example, in the legal system of the Republic of Srpska, Montenegro and Croatia, the expropriation award can determine in two forms: natural and monetary. The natural form implies providing some other appropriate immovability as ownership or co-ownership. When it is about the cash payments, a firm stand in comparative law was taken that the expropriation award amount, for reasons of fairness, cannot be lower than the market value of immovability which expropriates.

The immovability can be expropriated completely or incompletely. With the complete expropriation, there an owner of the expropriated immovability is changed, owing to the construction of commercial, residential, communal, educational, cultural and other similar buildings of general interest. With the incomplete expropriation, there establishes the official manner for immovability or fixed time limit land lease.

The procedure of expropriation realizes in three phases. In the first one, public interest determines in the presence of administrative authority, while in the second phase, the procedure of expropriation is implemented and the decision on expropriation is reached. The first and second phases of this procedure realize in the presence of

4 Trgovcevic Prokic - Giving an expert opinion (expertise) in extra-judicial procedure, Proceedings „Problemi vestacenja u krivicnom, parnicnom I javnobeleznickom postupku”, Glosarijum, Belgrade; Giving an expert opinion in extra-judicial procedure and notary public procedure, Proceedings „Vestacenja - sporna pitanja, “ Glosarijum, 2008; Giving an expert opinion in extra-judicial procedure, Proceedings „Primena novog Zakona o vestacenju, “ Glosarijum 2010; Giving an expert opinion in extra-judicial procedure and notary public procedure, Proceedings „Prirucnik o vestacenju.“ 
administrative authority, while the third phase realizes in $\operatorname{court}^{5}$, if there was no agreement between an owner of immovability and a final user of expropriation. In this last phase, the amount of expropriation award is determined and a final user is ordered to pay the expropriation award.

The right of ownership of agricultural land can be deprived or limited only in public interest determined by the law or by a governmental decision ${ }^{6}$ In the comparative law, it is strictly regulated that the award for deprived agricultural land determines in a natural form, by vesting an estate in some other adequate estate of the same structure and class or an appropriate value on the same location, ${ }^{7}$ especially if an owner of immovability earns profit from this immovability. If the expropriation user is not capable to offer adequate estate, then the expropriation award pays in cash.

\section{Procedure on the request for the agricultural land restitution}

Agricultural land is property of the general interest, which uses for agricultural production and estate which can bring to purpose for agricultural production. It is arable land: ploughed fields, gardens, orchards, vineyards, meadows, pastures, fish ponds, reeds and swamps. It cannot be used for some other purposes, except in cases provided by the law. ${ }^{8}$ Measures by which regulate the improvement of natural and ecological conditions of this estate are: land consolidation and land reclamation.

The right of ownership of agricultural land can be deprived or limited only in public interest determined by the law.

In domestic law, the procedure for restitution of land that was deprived was regulated

5 New item was introduced in Croatian law in terms of competence in the process of expropriation in regard to the previous legal resolutions. An administrative authority is primarily competent to conduct the expropriation procedure and issues the resolution on expropriation (paragraph 25, posture $1 \mathrm{LE}$ ). If no agreement is reached in the presence of a competent administrative authority, the competent administrative authority doesn't refer a case to the court, but issues the resolution on expropriation award.

6 Clause of paragraph 2 of the. "Official Gazette of RS" no. 53/95, "Official Gazette of SRY" no. 16/2001 - decision of SCC and "Official Gazette of RS" no. 20/2009 and 55/2013 Decision of CC, hereinafter: LE Serbia. The same solutions have also other laws in the region, and in that way the Law on Expropriation "Official Gazette of Republic of Srpska 112/06", hereinafter: LE of the Republic of Srpska (paragraph 6), clause of paragraph 14 of the Law on Expropriation "Official Gazette of R. Montenegro"no. 55/2000, 12/2002, 2/08, hereinafter: LE Montenegro, clause of paragraph 13 The Act on Expropriation and determination of expropriation award. Narodne novine, no. 74/2004, hereinafter: LE of Croatia.

7 Clause of paragraph 15 of LE of Serbia, clause of paragraph 35of LE of Montenegro.

8 Clause of paragraph 1 and 2 of the Law on Agricultural Land. "Official Gazette of RS" no. 62/2006, 65/2008, o.law 41/2009 and 112/2015

EP 2016 (63) 4 (1281-1295) 
by the special law. The Law on $\mathrm{ALF}^{9}$ regulates the method of restitution and the expropriation award for estate, confiscated due to defaults and the compulsory repurchase of agricultural products, and the estate which was assigned to economic organizations. ${ }^{10}$ This estate, according to previous regulations and conducted proceedings, has changed into public ownership. Ex-owner has the right to restitute deprived estate in the specific period of time, if he submitted a request for the return of confiscated estate until the year 1998. The right to award, instead of the return in a natural form, an owner has in the situation when various facilities or ball parks have been built on this land, or if raised permanent plantations, or if the estate has been alienated from public ownership. The award can be paid-up to ex-owner even if agricultural land was proclaimed for urban constriction land in the meantime. ${ }^{11}$

The proceedings for the restitution of deprived agricultural land were conducted in the presence of the Commission for the conduct of proceedings and making decisions on requests for the restitution of land. The obligation to pay the award had an organization which has used deprived estate at the moment of the award determination. If the deprived estate is in private ownership, the award was covered by an organization which had alienated the estate from public property. The obligation of a municipality and the Republic of Serbia to pay the award for deprived estate results also in situation when an organization is not capable to pay the award. It means that it is about the subsidiary guarantee of the municipality and the Republic of Serbia in terms of payment of awards. The agreement in terms of the award could be made in the presence of the Commission. Several types of award can be anticipated by the agreement, for example, that instead of returning the confiscated estate some other estate gives in exchange, to give shares or to pay the award in cash. Based on the agreement or the resolution of the Commission, ex-ownership or his/her legal successors can enrol in public books as owners of the restored estate.

The Commission for the conduct of proceedings and making decisions on requests for the restitution of land has the task to determine the right to pecuniary compensation to ex-owner. If the agreement on the form and amount of award hasn't been come to, the Commission for the conduct of proceedings and making decisions on requests for the restitution of land has been obliged to submit the case files to the competent court in order that the court in extra-judicial procedure could make a decision on the expropriation award for deprived estate.

9 Law on method and terms of recognition of rights and restitution of land that has switched to public property on the basis of the agricultural land fund and confiscation of outstanding liabilities and compulsory purchase of agricultural products "Official Gazette of $R S$ 'no.18/1991, 20/1992 and 42/98, hereinafter: Law on ALF.

10 Law on Agricultural Land Fund in social ownership and allocation of land to agricultural organizations "Official Gazette of FNRY” no. 22/53, 22/53, "Official Gazette of SFRY", no. 10/6, "Official Gazette of RS" no. 5/71 and 52/73 and "Official Gazette of SAPV" no.26/72

11 Supreme Court of Serbia. Rev. 2762/05 from 21.12.2005 


\section{Procedure in order to determine the expropriation award in court}

The expropriation, as a form of forced deprivation or the restriction of property rights of immovability owner, is done with the expropriation award which cannot be lower than the market one, according to the Constitution.

The expropriation procedure is regulated by the Law on Expropriation. If the agreement on the award was not achieved in the presence of an administrative authority between the expropriation owner and ex-owner of the expropriated immovability, an administrative authority is obliged to submit the case files to a competent extra-judicial court.

Nonetheless, the obligation of an administrative authority is to submit the case files to a court in situation when the agreement in the presence of this authority wasn't concluded in public interest. The agreement wasn't concluded in public interest: if it was concluded at the expense of public funds users, if it wasn't in accordance with the imperative regulations or significantly higher award than the market price of immovability in the moment of an agreement conclusion was agreed, by the agreement on award. ${ }^{12}$

The extra-judicial procedure for the determination of award for expropriated immovability conducts ex officio. The law anticipates the institution of proceedings at the initiative of participants in case when authorized administrative authority, after the decision on expropriation, doesn't submit the case files to the court within two months, since the agreement on the award amount wasn't achieved. This proposal doesn't have the character of the proposal by which institutes a proceeding. In this case, a proceeding institutes ex officio, because a participant had informed the court that there is a need for the institution of a proceeding (Stanković, Trgovčević Prokić, 2016).

The Court decides in council about the immovability expropriation award, so this legal matter is the aberration from the rules on the individual trial in extra-judicial matters (Stanković, Mandić, 2013).

Owing to the award determination for the expropriated immovability in judicial proceedings, a legislator tended to provide the equality of parties in the procedure of the award determination of the expropriated immovability, by the principles of orality, directness and the state of being contradictory.

Since the proceedings are contentious, the legislator has anticipated holding the compulsory hearing. The court must provide to participants to declare on the outcome of argumentation in accordance with the justice principle (Stanković, Trgovčević Prokić, 2016). Furthermore, there is possibility for participants to even up at a hearing for oral argument.

12 The resolution of the Supreme Court of Cassation in Belgrade, Rev. 827/11, $7^{\text {th }}$ July 2012 “", If the findings and expert opinion indicate that the value of assigned immovability (valorised and reduced for purchase price) exceeds the market value of the expropriated immovability, which was given in exchange, then conditions for determination of expropriation award for expropriated immovability are not fulfilled."

EP 2016 (63) 4 (1281-1295) 


\section{Territorial jurisdiction of the court}

Territorial jurisdiction of the extra-judicial court is determined by the principle forum rei sitae, in a way that for this procedure implementation is competent a basic court, in which territory the expropriated immovability is located.

\section{Urgency of the procedure}

The urgency procedure is anticipated in domestic (and regional law) ${ }^{13}$. Since the procedure is urgent, in this case cannot come to the adjournment due to death of owners of expropriated immovability and loss of the capacity of the expropriated immovability owner. In these situations, in order to make the proceeding uninterrupted, the court is obliged to appoint a temporary legal representative for heirs of the deceased owner of immovability, i.e. legally incompetent immovability owner, and it informs a trustee's authority about it, authorised to make decisions on appointing a temporary legal representative. In that way, with that listed legal solution, the interests of the owner himself (who lost his legal capacity) and an heir of the deceased owner are optimally protected too, depending on the reason that entered upon during the proceeding.

Absence of ex-owner of the expropriated immovability from hearing doesn't result in the occurrence of the legal fiction of withdrawal of the proposal. ${ }^{14}$ It is the official extrajudicial procedure, not initiated by the proposal, therefore the absence of participants ex-owner of expropriated immovability from hearing doesn't make those consequences anticipated for such situation in those proceedings initiated by the proposal.

\section{Obsolescence}

The request for the award of actually expropriated immovability never expires, as well as the rights to property right protection. ${ }^{15}$

The prescriptive period in terms of an adjudicated award for the expropriated immovability starts to run from the moment of the formation of an agreement, i.e. make the decision on the expropriation award.

13 In the regional law was regulated that expropriation award procedure must be finished within three months in court, starting from the day of initiation of judicial proceedings. Paragraph 159 of the Law on extra-judicial procedure, "Official Gazette of the Republic of Srpska"no. 36/09, hereinafter: LEJP of R.Srpska. Paragraph 160 of the Law on extrajudicial procedure “Official Gazette of Montenegro"no. 27/2006, hereinafter: LEJP of Montenegro. It is anticipated in Croatian law that a date of summons must be appointed within eight days (paragraph 59 of LE of Croatia).

14 The reply was determined at the session of the Court of Appeal Civil Department in Belgrade, held on $19^{\text {th }}$ November 2013. The Court of Appeal was forced to formulate the response to a question asked by the local court, because it was determined that lower instance courts know insufficiently the nature of this extra-judicial procedure.

15 See the verdict of the Court of Appeal in Novi Sad, Gž 316/13 on 24 ${ }^{\text {th }}$ September 2014 


\section{Participants (parties) in the proceedings}

Entities of a material-legal relation, which appeared with regard to the done expropriation, are ex-owner of the expropriated immovability and the expropriation owner. The owners of confiscated immovability don't have the position of unique co-participants, while the court is obliged to make decisions on the proposal for determining the award and in situation when only one of the parcel owners requires the award to be paid. ${ }^{16}$

The expropriation user can be the Republic of Serbia, the autonomous province or a local authority unit, represented by a competent solicitor. ${ }^{17}$ If the expropriation was done for the purpose of another legal entity, this legal entity has also the status of participant in this proceeding.

The Court is bound by the content of the decision of confiscation of estate ${ }^{18}$, because type, status and area of expropriated estate were determined by this resolution. This resolution must have the status of finality and not to be cancelled in the eventual proceedings after the extraordinary remedies. Besides, this resolution is the basis for giving orders to a competent authority or an expert to report.

\section{The amount of the expropriation award}

The amount of the expropriation award is determined after the market price of expropriated immovability, and according to circumstances at the moment of the conclusion of an agreement on the award amount, ${ }^{19}$ if the agreement wasn't accomplished according to circumstances at the moment of making decision on the award.

Data on the immovability market price is provided to the court by an authority competent for the determination of tax on transfer of absolute rights to immovabilities. Carrying out proofs by giving an expert opinion owing to the determination of a market price amount with the previous resolution ${ }^{20}$, which has affected, on the one hand, to

16 Resolution of the High Court in Leskovac Gž. no. 1328/13 on $1^{\text {st }}$ October 2013. In this decision of the court is spoken falsely of unique co-litigants, although extra-judicial procedure doesn't know this institute, which is characteristic for the litigantory procedural law. Presumably, the court has interpreted falsely the rule on appropriate application of rules of the civil procedure, which can be applied in case of legal gap. The appropriate application of rules of other procedure doesn't mean literal, but creative application, so the court was obliged to adapt, during the interpretation and application of a rule, this rule in accordance with principles, goals and spirit of the extra-judicial procedure.

17 Law on Public Legal Office "Official Gazette of RS” no. 55/14

18 Resolution of High Court in Belgrade, Gž. no. 9350/13 on $11^{\text {th }}$ December 2014

19 Clause of the paragraph 42 of LE.

20 LE of Serbia ("Official Gazette of RS" no. 16/2001). Innovation was introduced by LE ("Official Gazette of RS"no. 20/2009) which has determined that a body authorised for the assessment of tax on transfer of immovability absolute rights carries out an assessment of the market value(clause of paragraph 15). In the Croatian law, the court assesses the market value through appraisers and court experts, while it doesn't have such knowledge.

EP 2016 (63) 4 (1281-1295) 
the amount of proceeding costs, and on the other hand, it has led to dragging out the proceeding if it has been needed to repeat it. Obtaining a professional opinion is required by a new legal solution (Trgovčević Prokić, 2010). The authority from which the court seeks information on a market price of immovability, on the one hand, does not dispose with necessary data (no copy of a plan, land registry insert or immovability sheet), and on the other hand, it is not on the spot in order to determine the amount of a market price, according to direct observation of the situation on the field and the provision of information on estate quality, and on the other hand, it doesn't offer arguments for its report. The report has to offer arguments by an authority which informs the court about a current market price of expropriated immovability ${ }^{21}$ in order to let the participants to plead, but also for the court to check the accuracy of the appraisal. If there states only a price in the report, without explanations and stating all parameters which were taken into consideration during its determination and appraisal, then there excludes also the possibility of participants to declare regarding its correctness and the evaluation of such appraisal carried out by the court (Stanković, Trgovčević Prokić, 2016).

The Cassation Court of Serbia has taken a stand that the report of an authority represents only a starting point for determining the market value of expropriated immovability, because participants can require the presentation of evidences by giving an expert opinion. ${ }^{22}$ Some regional laws are also familiar with such solution. ${ }^{23}$

In the procedure of determining the expropriation award, there was excluded the possibility that a participant submit a private document which contains findings and opinion of a court expert, who is engaged by the party, taking into consideration that in this case it is not about expertise, but about taking evidences by reading a private

21 According to a standpoint of the Supreme Court of Cassation "the assessment of the market value of immovability provided by the Tax Administration must be argumented and not flatrate. "The sentence from the Supreme Court of Cassation resolution Rev 467/014 on 28 $8^{\text {th }}$ January 2015 was determined at the meeting of Civil Department on $7^{\text {th }}$ April 2015.

22 Clause of paragraph 136, Zakon o vanparničnom postupku, of Serbia

23 It is anticipated in the Croatian law that the amount of expropriation award is determined by an appraiser, and if necessary, even a court expert. See also clause of the paragraph 162 of Zakon o vanparničnom postupku of Montenegro, which anticipates an identical solution. 
document, as the rules of LCP anticipate. ${ }^{24}$

We consider that a court expert, by his expertise, helps the court and parties in the proceedings in order an award to be determined proper and fair. If there is a need for giving an expert opinion in order to determine an award which amount is debatable among participants in the proceedings, because they disagree concerning the amount of market price from an obtained report, the court is obliged to make decision on this evidence presentation and to determine the expertise by an expert of a particular profession.

In the determination of agricultural land market price, a court expert of agricultural profession is obliged to take into consideration the position of estate, class, culture and real situation of the immovability. The amount of market price of agricultural land will depend on its position, class, culture and purpose, with the fact that it is also important whether ex-owner has used this estate as the agricultural one.

In the determination of a market price for orchards and vineyards, a court expert of fruit profession should determine a market price of unredeemed investments invested in raising and maintaining such vineyard, as well as the amount of the same yield which would this orchard/vineyard provide considering its age and productiveness for as many years as necessary to raise (and to achieve full ripeness) vineyard or orchard, with the fact that, besides a determined value of plantation, there also determines a price of estate. $^{25}$

When the market price for expropriated nursery bed is determined, an expert should determine the market price for agricultural land and the planting material value.

If the expropriated immovability is ripen forest, an expert of forestry profession should determine a value of forest ranges and other forest products in accordance to market prices on a truck route or some other contracted purchasing site, with the fact that he should reduce the market value for the amount of production costs.

In the determination of an award for expropriated young forest, a court expert should determine, besides the market price of estate, also the market price of young forest

24 The Law on Civil Procedure “Official Gazette of $R S$ ”no. 72/11, 49/13, 74/13 and 55/14, hereinafter: LCP. There should notice that the Law on Civil Procedure from the year 2011, in addition to judicial expertise, anticipates also private discovery and a court expert's opinion. Legislator has foreseen the possibility that a party encloses, besides his report (indictment, countercharge, response to an indictment), also a document which contains the discovery and opinion of a court expert of adequate profession, in order to clarify the fact that requires expert knowledge the court doesn't have. However, in regard to this private document is not applicable procedural regime, anticipated by the law regarding the expertise as evidence, because this evidence, as the private document, takes by reading the identity document. In detailed about it: Stankovic G., "Gradjansko procesno pravo", the first volume, Parnicno prcesno pravo, Megatrend University, Belgrade, 2013, p 455

25 Clause of paragraph 15, posture of LE. There should notice that LE of the Republic of Srpska anticipates more detailed solution (clause of paragraph 57).

EP 2016 (63) 4 (1281-1295) 
taking into consideration the costs for raising such forest, increased for a value growth factor by which ripen forest value is achieved..$^{26}$

When an expert gives his expert opinion, the participants plead about it. They have the right to search for explanations and extensions, aiming to determine the market price of expropriated immovabilities proper and fair, and the amount of award for them according to the determined value in such way. ${ }^{27}$

A court expert, i.e. the Tax Administration should state in an explanation of the report whether the comparison of prices was done in accordance to a selling price in the contract; whether income expected from estate could serve as a criterion, taking into consideration the purpose of estate and the activity of a proposer; whether so called neighbouring transactions were analysed if there was no contract of sale for this type of estate in a cadastral municipality where these immovabilities are located.

After the expertise is done, the court is obliged to make decision about the amount of award for the expropriated immovability. In the process of decision-making, personal and family circumstances of ex-owner takes into consideration as a corrective for the eventual increase in the expropriation award amount. They take into consideration also when there are facilities used for livestock breeding or agricultural products located on the expropriated estate, when the award is determined in a natural form by vesting an estate in some other facility in order for owner to continue with his activity. Besides, although an owner doesn't have the right to invest in agricultural land and immovability in general, after the institution of expropriation proceedings, he has the right to necessary expenses ${ }^{28}$. Before he makes a decision, the court is obliged to search from an expert to plead regarding expenses necessary for using the immovability.

\section{Agreement}

In proceeding in the presence of a district court or municipal administration, the parties can make an agreement: about form and size of an award, about vesting some other immovability or co-ownership instead of expropriated immovability, about the amount of expropriation award, about mutual payments of differences regarding a value of immovability, about moving facilities (buildings) from the expropriated immovabilities to another allowed location, about building entrances, passages and access roads, as well as other legally permitted performances.

In domestic law, the clauses of the Law on Expropriation primarily refer to a negotiated

26 Clause of the paragraph 57 posture 3 of LE of R.of Srpska: "When it is about raising young forest created artificially, then costs are determined at the level of afforestation costs, while the costs of young forest created naturally are calculated at the level of artificial afforestation costs."

27 Resolution of the High Court in Novi Sad, buss. Ho. Gž.5751/10 on 30 th $^{\text {th }}$ March 2012

28 Paragraph 50 of LE of Serbia 
procedure for determining the award for expropriated immovability. ${ }^{29}$ If the parties have agreed in the presence of the court and the court has found out that it hasn't been inconsistent with the regulations, public order and good practice, it can base its decision on a reached agreement. In this agreement the deadlines for discharging mutual obligations are determined.

\section{Resolution}

The resolution has a condemnatory character. The court orders to a user of expropriation to pay off to ex-owner a pecuniary compensation after the price determined in the amount of market value of deprived agricultural land. The court is obliged to determine also deadline for execution

The court also determines in an order of the court that the expropriation user is obliged to pay interest on the fixed amount of award until its final payment. Interest runs from the day of the decision on expropriation award. It is about interest paid by a debtor, due to delay in discharging of its obligation and it is certain form of sanction owing to default. $^{30}$

However, there should notice that pecuniary compensation on request for estate restitution is otherwise regulated in regard to the expropriation award. According to the clauses of the Law on Agricultural Land Restitution, the pecuniary compensation is done in equal quarterly instalments, within ten years, starting from the expiration of one year from the date of resolution in effect, since interest is paid to mature instalments. The interest is accrued and paid for every mature quarter instalments, starting from the validity of a court decision to a concrete maturity of instalment, and not when a debtor is late, because in this case it is about revalued interest ascertained owing to the preservation of the real value of money in inflationary conditions. ${ }^{31}$ The interest is legally recognized valorisation of award due to the protection of ownership interests of persons whose estate was deprived.

Besides the expropriation award for expropriated agricultural land, the court will decide on eventual appurtenance of expropriated immovability, such as young plantations, built facilities, sown crops etc. if they were existing in time of expropriation and if there wasn't any abuse of property rights (if appurtenances hadn't appeared owing to acquiring permitted economic profit but due to the apparent increase in value of expropriated immovability).

In domestic law, the registration of rights to expropriated immovability is done according to the final (valid) resolution on expropriation. If other immovabilities are adjudicated to ex-owner as the expropriation award, then during the registration of

29 Clause of paragraph 56-62 of LE of Serbia

30 Clause of paragraph 277 of the Law on Bonded Relations, "Official Gazette of SFRY"no. 29/78, 39/85, 57/89 and "Official Gazette of SRY"no. 31/93, hereinafter: LBR.

31 The Constitutional Court of Serbia, Už 3720/2012on $9^{\text {th }}$ April 2015

EP 2016 (63) 4 (1281-1295) 
property rights for immovabilities, got in exchange for the expropriated immovability, there requires also an executive document on award.

In some regional legal systems, when registering the immovability, besides the expropriation resolution in effect, there also requests the evidence on paid expropriation award. ${ }^{32}$ We consider that the resolution from the regional law is better, while there requires the evidence on paid expropriation award, because it contributes to complete discharge of an obligation of a final user. According to resolutions in domestic law, the final user can register in land register before the award is paid. In that way, a legislator favours the interests of expropriation users in regard to ex-owner, who is forced to wait for the award payment, which can be devaluated meanwhile, and on the other hand, this complicates him the possibility to buy another estate.

\section{Costs of the proceeding}

Final user, according to an explicit legal provision, bears the costs of the proceeding, because the proceeding was conducted in his interest. ${ }^{33}$ All briefs and decisions in this proceeding are free of paying a court fee.

\section{Legal remedy}

According to the general provisions, participants have the right to appeal within 15 days from a day of the decision acceptance.

Legal capacity to file an appeal belongs to the participants and a competent legal adviser. The participants have the right to audit, depending on validity criteria.

\section{Administrative transfer}

The award amount for the expropriated agricultural land, but also other immovability, natural resources in state and public property in general, is determined differently depending on whether a holder of property right of estate, i.e. some other natural resource has come through the contract for valuable consideration or the opposite one. In the procedure of award payment for expropriated estate, and when it is about administrative transfer, then ex-owner of expropriated estate has no right to award in the amount of the market price of the estate. He has the right to award in the amount of invested work and resources into the estate. Administrative transfer implies that a right holder of agricultural land or some other natural resources has acquired this immovability without reparation. ${ }^{34}$

32 Clause of paragraph 58 of LE of Montenegro, clause of paragraph 56 of LE of Croatia.

33 According to previous resolutions which were in force in the law of other Yugoslav state (Law on Expropriation, “Official Gazette of SFRY”no. 11/68), the court was determining the judicial proceedings costs proportional to success of the parties in the proceedings.

34 Resolution of the High Court in Belgrade, Gž. No. 4050/12 on $5^{\text {th }}$ June 2013 


\section{Returning the received expropriation award}

The extra-judicial court is not competent for the case that there requires the determination of award by the proposal, which the final users of expropriation are obliged to return to a proposer. In this situation, the extra-judicial procedure must be suspended, because it is about returning the paid award, i.e. it is about the obligation to return what opponents of the proposer have received, regarding to a basis which later become invalid. ${ }^{35}$ The Civil Court is competent in this case.

\section{Literature}

1. Aranđelović, D. (1933): Građansko procesno pravo Kraljevine Jugoslavije, Beograd.

2. Britvić, V.B. (2009): Pravo izvlaštenja nekretnina u Hrvatskoj, Opći režim i posebni postupci, Zbornik Pravnog fakulteta u Splitu, vol. 46, no. 1, pp. 201-217.

3. Počuča, M., Drašković, B., (2015): Promena namene poljoprivrednog zamljišta u građevinsko-praksa i tenedencije,Naučno društvo agrarnih ekonomista Balkana, Ekonomika poljoprivrede, Beograd, vol. 62, no. 2, pp. 285-576.

4. Stanković, G. (2013): Građansko procesno pravo, sveska prva, Parnično procesno pravo, Megatrend univerzitet, Beograd.

5. Stanković, G., Mandić, Lj. (2013): Vanparnično procesno pravo, Kosovska Mitrovica.

6. Stanković, G., Trgovčević Prokić, M. (2015): Komentar Zakona o vanparničnom postupku, Službeni glasnik, Beograd.

7. Todorović, M. (1991): Komentar Zakona o načinu i uslovima priznavanja prava o vraćanju zemljišta koje je prešlo u društvenu svojinu po osnovu poljoprivrednog zemljišnog fonda i konfiskacijom zbog neizvršenih obaveza iz obaveznog otkupa poljoprivrednih proizvoda, Novinsko-izdavačka ustanova Službeni list SFRJ.

8. Trgovčević Prokić, M. (2002): Veštačenje u vanparničnom postupku, Zbornik radova, Problemi veštačenja u krivičnom, parničnom i vanparničnom postupku, redaktor Nebojša Šarkić, Beograd, urednik Katica Borbar, Glosarijum, Beograd.

9. Trgovčević Prokić, M. (2008): Veštačenje u vanparničnom i javnobeležničkom postupku, Zbornik radova Veštačenja - sporna pitanja, redaktor Nebojša Šarkić Glosarijum.

10. Trgovčević Prokić, M. (2010): Veštačenje u vanparničnom postupku, Zbornik radova, Primena novog Zakona o veštačenju, redaktor Nebojša Šarkić, Glosarijum.

11. Trgovčević Prokić, M. (2011): Veštačenje u vanparničnom i javnobeležničkom postupku, Zbornik radova Priručnik o veštačenju, Glosarijum.

12. Triva, S., Dika, M., Belajac, V. (1986): Građansko procesno pravo, Zagreb, Narodne novine.

35 Clause of the paragraph 210, posture 2, LBR.

EP 2016 (63) 4 (1281-1295) 
13. Culja, S. (1938): Građansko procesno pravo kraljevine Jugoslavije, II sveska, Vanparnični postupci ( izvršno,stečajno i vanparnično procesno pravo) Izdavačko i knjižarsko preduzeće, Geca Kon“,Beograd.

\section{LAWS}

1. Zakon o vanparničnom postupku „Official Gazette of the RS”, no. 25/82 i 48/88 „, Official Gazette of the RS “,no. 46/95 - other law, 18/2005 - other law, 85/2012, 45/2013 - other law, 55/2014 i 6/2015.

2. Zakon o vanparničnom postupku, „Official Gazette of the Republika Srpska“ "no. $36 / 09$

3. Zakon o vanparničnom postupku, „Official Gazette of Montenegro“" no. 27/2006.

4. Zakon o veštačenju, „Official Gazette of the $R S^{\text {“, no. 44/2010 }}$

5. Zakon o oeksproprijaciji,, Official Gazette of the RS ", no. 53/95, "Official Gazette of Federal Republic of Yugoslavia", no. 16/2001 and "Official Gazette of the $R S^{\prime \prime}$ no. 20/2009 i 55/2013

6. Zakon o eksproprijaciji, „, Official Gazette of the Republika Srpska,“ no. 112/06.

7. Zakon o eksproprijaciji „Official Gazette of Montenegro,“ no. 55/2000,12/2002, 21/08.

8. Zakon o izvlaštenju i određivanju naknade, Public paper, no. 74/2004.

9. Zakon o obligacionim odnosima, „, Official Gazette of Socialist Federal Republic of Yugoslavia", no. 29/78, 39/85, 57/89 and "Official Gazette of Federal Republic of Yugoslavia" "no. 31/93.

10. Zakon o parničnom postupku, „Official Gazette of the RS,“ br.72/11, 49/13, 74/13 i $55 / 14$

11. Zakon o poljoprivrednom zemljištu, " Official Gazette of the RS “, no. 62/2006, 65/2008 - other law, 41/2009 i 112/2015.

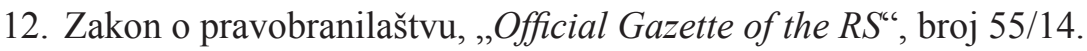

13. Zakonu o poljoprivrednom zemljišnom fondu društvene svojine i dodeljivanju zemlje poljoprivrednim organizacijama, „Official Gazette of the Socialist Federal Republic of Yugoslavia”, no. 22/53, 22/53, "Official Gazette of Socialist Federal Republic of Yugoslavia “no. 10/65, „Official Gazette of the RS,” no. 51/71 and $52 / 73$.

14. Zakon o načinu i uslovima priznavanja prava i vraćanju zemljišta koje je prešlo u društveniu svojinu po osnovu poljoprivrednog zemljišnog fonda i konfiskacijom zbog neizvršenih obaveza i obaveznog otkupa poljoprivrednih proizvoda, ,, Official Gazette of the RS “, no.18/1991, 20/1992 and 42/98. 


\title{
EKSPROPRIJACIJA POLJOPRIVREDNOG ZEMLJIŠTA
}

\author{
Milena Trgovčević Prokić ${ }^{36}$ Milan Počuča ${ }^{37}$
}

Rezime

Eksproprijacija je prinudno lišavanje svojine u javnom interesu i predstavlja jedan vid ograničavanja prava svojine. Suštinsko pitanje eksproprijacije je pitanje pravične naknade koje se duguje sopstveniku oduzete nepokretnosti. Prilikom određivanja pravične naknade potrebno je pronaći merila pomoću kojih će se zaštititi obe strane $u$ pronaći ravnoteža u proporcionalnosti društvenog i individualnog interesa. $U$ postupku za određivanje naknade za eksproprisanu nepokretnost sud ima zadatak da odredi pravičnu naknadu tako da ne dođe do neosnovanog obogaćenja sopstvenika nepokretnosti $i$ osiromašenja korisnika eksproprijacije ili obrnuto.U radu se analiziraju pravila po kojima se postupa kad postoji potreba da se u javnom inteesu izvrši eksproprijacija i odredi pravična naknada koja treba da pripadne sopstveniku eksproprisane nepokretnosti.

Ključne reči:eksproprijacija nepokretnosti, poljoprivredno zemljište, sporazum, naknada, upravni organ, vanparnični postupak, stručno mišljenje, veštačenje.

36 Dr Milena Trgovčević Prokić, Sudija, Prvi osnovni sud Beograd, Kostolačka Ulica br. 89, Beograd, Srbija, Telefon: +3816363308 339, E-mail milenaprok@gmail.com

37 Vanredni profesor, dr Milan Počuča, Prodekan za nauku kvalitet i razvoj, Univerzitet Privredna akademija u Novom Sadu, Pravni fakultet, Ulica Geri Karolja br. 1, Telefon: +381 21400 499, E-mail pocuca@pravni-fakultet.info

EP 2016 (63) 4 (1281-1295) 